\title{
Pengaruh Literasi Keuangan, Kontrol diri dan Penggunaan E-Money terhadap perilaku konsumfit pekerja produksi PT Pertamina Balikpapan
}

\author{
Hermin Nainggolan \\ Sekolah Tinggi Ilmu Ekonomi Balikpapan \\ herminnainggolan@stiebalikpapan.ac.id
}

\begin{abstract}
Penelitian ini bertujuan untuk mengetahui pengaruh literasi keuangan, control diri, dan penggunaan e-money terhadap perilaku konsumtif pekerja produksi PT Pertamina Balikpapan. Perilaku konsumtif (Y) sebagai variabel terikat sedangkan literasi keuangan (X1), kontrol diri (X2), dan penggunaan e-money (X3) sebagai variabel bebas. Hasil uji asumsi klasik menyatakan bahwa penelitian ini terbebas dari multikolinearitas, autokorelasi, heteroskedastisitas, serta terdistribusi normal. Hasil regresi linier berganda diperoleh hasil $\mathrm{Y}=14,883-0,354 \mathrm{X} 1-0,173 \mathrm{X} 2+$ $0,303 X 3$ + e. Hasil uji hipotesis dengan uji $f$ diketahui hasil $f$ hitung $(26,139)>\mathrm{f}$ tabel $(2,67)$ dan tingkat signifikansinya $0,000<0,05$ sehingga hipotesis pertama diterima. Sedangkan hasil uji t menunjukkan bahwa secara parsial literasi keuangan merupakan variabel bebasyang paling dominan dengan hasil $-t$ hitung $(-4,454)<-t$ tabel $(-1,9785)$ dan tingkat signifikansinya $0,00<0,05$ sehingga hipotesis kedua diterima. Koefisien determinasi menunjukkan $\mathrm{R}^{2}=0,364$ yang artinya kontribusi variabel bebas sebesar 36,4\%, sedangkan sisanya sebesar 63,6\% dijelaskan oleh variasi lain yang tidak diteliti dalam penelitian ini
\end{abstract}

Keywords $\quad$ Literasi Keuangan, Kontrol Diri, Penggunaan E-Money, Perilaku Konsumtif

\section{Pendahuluan}

Perilaku konsumsi masyarakatsangat dipengaruhi oleh perkembangan zaman yang semakin modern, teknologi yang berkembang pesat kehidupanmanusia yang dinamis, serta tingkat literasi seseorang diiringi dengan tingkat pendapatan yang semakin meningkat. Pola perilaku konsumsi masyarakat saat ini telah bergeser, dari sekedar pemenuhan kebutuhan primer,berkembang menjadi pemenuhankebutuhan sekunder, tersier dan cenderung bersikap konsumtif.Kebutuhan primer yaitu kebutuhan yang mutlak harus dipenuhi untukkelangsungan hidup manusia. Kebutuhan primer disebut juga kebutuhan pokok. Seandainya kebutuhan primer tidak terpenuhi, kelangsungan hidup manusia akan terganggu. Contoh kebutuhan primerantara lain makan, minum, pakaian, dan tempat tinggal.

Kebutuhan sekunder adalah kebutuhan yang dipenuhi setelah kebutuhan pokok terpenuhi. Kebutuhan sekunder merupakan kebutuhan atau pelengkap kebutuhan pokok. Kebutuhan sekunder setiap orang berbeda-beda.Contoh kebutuhan sekunder adalah perabot rumah tangga, tas, sepeda motor, meja kursi, alat olah raga.

Kebutuhan tersier adalah kebutuhanyang dapat dipenuhi setelah kebutuhan primer dan sekunder terpenuhi dengan baik. Pada umumnya, pemenuhan kebutuhan tersier dilakukan oleh orang-orang yang berpenghasilan tinggi dan biasanya digunakan untuk menunjukkanstatus 
sosial. Contoh kebutuhan tersier antara lain kebutuhan rumah mewah,perhiasan, berlian, dan mobil mewah. Setiap individu memiliki kebutuhan hidupnya masing-masing dimana semua kebutuhan tersebut berusaha untuk dipenuhi dengan cara yang berbeda-beda. Semakin tinggi keinginan individu dalam memenuhi keinginannya maka semakin banyak pula kebutuhan tersebut yangharus dipenuhi. Perilaku konsumtif merupakan perilaku membeli barang tanpa adanya pertimbangan yang kuat danlebih mengedepankan keinginan dari padakebutuhan.

Pemenuhan kebutuhan yang telah bergeser tersebut sangat penting artinya untuk mengantarkan individu pada kehidupan yang selaras dengan lingkungannya. Perilaku konsumtif adalah suatu tindakan yang tidak rasional dan bersifat kompulsif sehingga secara ekonomis menimbulkan pemborosan dan inefisiensi biaya. Tindakan konsumsi yang irasional dan kompulsif dapat dideskripsikan seperti ketika individu membeli barang atau layanan jasa dengantidak berdasarkan kebutuhan prioritas namun sekedar memenuhi hasrat dankeinginannya saja. Hal ini juga berkaitan dengan besaran tingkat literasi keuangan seseorang, yang mana terkadangseseorang tidak mengetahui mana hal yang dijadikan prioritas dikarenakanmemiliki tingkat literasi keuangan yangrendah.

Perkembangan teknologi komunikasi, elektronik dan keuangan juga mendukung masyarakat memiliki akses yang tanpa batas terhadap informasimengenai produk atau layanan yang diinginkan sehingga lebih mudahterpengaruh untuk bertindak konsumtif.Fenomena ini akan menjadi ancaman yang serius ketika tidak hanya terjadi pada orang dewasa melainkan juga padaremaja. Karena pola konsumsi setiapindividu terbentuk ketika usia remaja,apalagi remaja zaman sekarang sangatcepat menerima perubahan teknologiyang mana itu juga dapat berakibat buruk.Masa remaja berada pada usia 13-21 tahun, pada usia ini merupakan masa peralihan dan pencarian jati diri, remaja mengalami proses pembentukan dalam perilakunya, dimana para remaja mencari dan berusaha untuk mencapai pola diri yang ideal, hal tersebut menyebabkan para remaja mudah terpengaruh oleh berbagai hal di sekelilingnya, baik itu yang positif maupun yang negatif. Pengambilan keputusan konsumen yang terlihat irasional mendasari perilaku ikut- ikutan atau mode. Membeli sesuatu untuk memenuhi kebutuhan sebenarnya tidak menjadi masalah bahkan sudah menjadihal biasa, selama membeli itu benarbenar ditujukan untuk memenuhi kebutuhan hidupnya yang pokok atau yang benar-benar dibutuhkan atau kebutuhan primer. Keputusan dalam menentukan pilihan bukanlah pekerjaan yang mudah, sebabberdasarkan pertimbangan-pertimbangan tertentu. Karenanya manusia perlu belajarbagaimana menentukan pilihan, hal inilahyang dipelajari dalam ilmu ekonomi.Dengan demikian ilmu ekonomi membantu manusia agar upaya ke arah pemenuhan kebutuhan yang selalu langka tersebut bisa dilakukan dengan baik.

Perilaku konsumtif dapat dijelaskandengan melihat kebiasaan subjek dalamhal ini para pekerja produksi PT Pertamina Balikpapan yang lebih sering membeli barang untuk memenuhi keinginan bukan kebutuhan dari pada menabung atau investasi, suka berbelanja karena terpengaruh dengan discount, memilih mengisi waktu luang dengan teman-teman atau keluarga di coffee shop,mall, atau bioskop, dan menggunakan e- money sebagai media transaksi karena sedang trend, mudah, dan mendapatkan discount atau cashback. Selain itu, para pekerja juga menggunakan barangbermerek (baju, tas, sepatu, jam tangan, dan gadget) saat berada di lingkungan kerja. Adanya penggunaan e-money (Ovo, Gopay, Dana, LinkAja, Brizzi, dan lainnya) dikalangan para pekerja juga mempengaruhi perilaku dalamberkonsumsi karena 
kemudahan dalam pembayaran membuat para pekerja lebih mudah membelanjakan uangnya. Gaya hidup konsumtif ini akan terus terjadi jika para pekerja tidak mampu memahami bagaimana cara mengendalikan keinginan, mangelola keuangan dan mempertahankan pola hidup seimbang.

Berdasarkan fenomena masalah yang terjadi pada pekerja produksi PT Pertamina Balikpapan. Perilaku konsumtif dapat dipengaruhi oleh kondisi internal dan eksternal individu. Menurut beberapa penelitian terdahulu yang telah dilakukan, keputusan individu dalam berperilaku konsumtif dapat dipengaruhi oleh beberapa faktor yaitu literasi keuangan, kontrol diri, dan penggunaan $e$-money.

Pertama, literasi keuangan merupakan hal penting yang tidak bisadipisahkan dalam proses mengelola keuangan. Adanya pengetahuan keuangan dan literasi keuangan akan membantu individu dalam mengatur perencanaan keuangan pribadi, sehingga individu tersebut bisa memaksimalkan nilai waktu uang dan keuntungan yang diperoleh olehindividu akan semakin besar dan akan meningkatkan taraf kehidupannya.

Banyaknya masyarakat yang tidakmengerti tentang literasi keuangan sepertipengetahuan finansial, sehinggamenyebabkan banyak masyarakat yang mengalami kerugian, baik akibat penurunan kondisi perekonomian dan inflasi atau karena berkembangnya sistemekonomi yang cenderung boros dikarenakan masyarakat semakinkonsumtif. Dalam hal ini permasalahan kurangnya literasi keuangan juga terlihat pada para pekerja produksi PT Pertamina Balikpapan, penulis dari beberapa tahun sudah mengamati tentang kebiasaanpekerja. Setiap para pekerja yang sudah mencapai masa pensiun (umur 56 tahun), sebagian besar pekerja tidak memiliki tabungan yang cukup untuk masa pensiunnya, yang mana pada akhirnya uang pensiunannya digunakan untukmemenuhi kebutuhan hidup. Selain itu para pekerja baru dengan masa kerja kurang dari 3 tahun, sebagian besar masihbingung akan digunakan untuk apa danmau dikemanakan uang gaji bulanan ataupun uang bonus dari hasil kinerja tahunannya. Sehingga pada akhirnya uangitu ujung-ujungnya digunakan untuk hal- hal yang bersifat konsumtif. Literasi keuangan juga dapat diartikan sebagai tingkat pengetahuan dasar tentang pengelolaan keuangan, dari pendapatan sampai pengeluaran. Sering terjadi saat seseorang hendak membelanjakan uangnya. Dengan memahami literasi keuangan membantu individu agar terhindar dari perilaku konsumtif dan masalah keuangan. Para pekerja produksi PT Pertamina Balikpapankebanyakan hanya menjadikan literasikeuangan itu sebagai pemahaman saja tanpa penerapan atau memang sebelumnya belum mendapat edukasi dengan baik akan literasi keuangan. Dapat disimpulkan literasi keuangan para pekerja produksi PT Pertamina Balikpapan belum baik.

Kedua, kontrol diri merupakan cara individu dalam mengontrol perilaku, mengontrol kognisi dan mengontrol keputusan. Individu yang memiliki tingkat pengendalian diri yang tinggi akan mempertimbangkan terlebih dahulu apakah pembelian yang akan dilakukanitu merupakan pembelian yang benar- benar dibutuhkan atau tidak. Untuk permasalahan kontrol diri juga terlihat pada pekerja produksi PT Pertamina RUV Balikpapan. Yang mana tidak hanyapara pekerja junior (masa kerja kurangdari 3 tahun), para pekerja senior juga memiliki kasus yang sama. Jika parapekerja junior tidak bisa mengontrol diridikarenakan masih ingin menunjukkanjati dirinya ke orang sekitarnya terutamaseumurannya bahwasannya dia sudah bekerja dan kesuksesan itu dipandang daribarang-barang yang melekat pada dirinya.Kalau 
pekerja senior dikarenakan pendapatannya sudah dikatakan lebih dari cukup.Maka sering kali penulismemperhatikan, mereka membeli barang juga bukan berdasarkan kegunaan atau fungsinya akan tetapi lebih kearah gengsi.Ketiga, electronic money (e-money)

atau uang elektronik merupakan sebuahalat transaksi non tunai yang mana bentuknya bisa berbentuk chip based (e-money) ataupun server based (e-wallet). Perkembangan financial technologydalam hal pembayaran menjadi salah satugaya hidup masyarakat pada saat ini. Perubahan sistem pembayaran sangat pesat mengikuti perkembangan teknologi.Menurut Bank Indonesia jumlahelectronic money beredar di Indonesia semakin bertambah pesat. Hal ini berdasarkan dari data Bank Indonesia tahun 2020 dapat diketahui bahwa kecenderungan pemakaian sistem pembayaran non tunai semakin diminati oleh masyarakat. Hal ini dapat terlihat dari peningkatan jumlah e-money yang beredar di Indonesia pada tahun 2013 ke tahun 2019 terus meningkat dari 36.225.373 e-money menjadi 292.299.320e-money, menunjukkan pengguna $e$-money yang semakin bertambah. Dengan adanya sistem pembayaran elektronik ini mempermudah transaksi pembayaran. Alat pembayaran e-money juga dapat mempengaruhi pola hidup masyarakatmenjadi lebih efisien maupun lebih konsumtif. Sejak bulan maret 2019 dimana ada beberapa produk e-money yang dimerger menjadi linkaja, maka PT Pertamina sebagai perusahaan BUMNmengeluarkan kebijakan kepada seluruhpekerjanya agar memiliki akun linkaja sebagai bentuk sinergi antar BUMN.Yang mana kedepan setiap claim dinasataupun claim fasilitas pengobatanpekerja akan ditransfer via akun linkaja. Dengan adanya hal seperti ini juga dapat meningkatkan rasa ketertarikan pekerja produksi Balikpapan terhadap penggunaan -money lainnya dikarenakankemudahan, keamanan, kecepatan transaksi dan banyaknya promo-promo di platform e-money bisa meningkatkan sifatkonsumtif para pekerja.

\section{Landasan teori}

\section{a. Literasi Keuangan}

Literasi keuangan merupakan suatu keharusan bagi tiap individu agar terhindar dari masalah keuangan karena individu seringkali dihadapkan padatrade off yaitu situasi dimana seseorang harus mengorbankan salah satu kepentingan demi kepentingan lainnya. Kesulitan keuangan bukan hanya fungsi dari pendapatan semata (rendahnya pendapatan). Kesulitan keuangan juga dapat muncul jika terjadi kesalahan dalam pengelolaan keuangan miss management seperti kesalahanpenggunaan kredit dan tidak adanya perencanaan keuangan. Keterbatasan finansial dapat menyebabkan stres, dan rendahnya kepercayaan diri. Adanya literasi keuangan akan membantu individu dalam mengatur perencanaankeuangan pribadi, sehingga individu tersebut bisa memaksimalkan nilai waktu uang dan keuntungan yang diperoleh oleh individu akan semakin besar dan akan meningkatkan taraf kehidupannya. Memahami implikasi finansial yangditimbulkan dari keputusan keuangan merupakan hal yang mendasar dalam literasi keuangan.

Soetiono \& Cecep (2018) menyatakan bahwa literasi merupakan "kemampuan individu untukmenggun akan segenap potensi dan keterampilan yang dimiliki dalam hidupnya sehingga pengertian literasi mencakup kemampuan seseorang dalam mengelolah dan memahami informasisaat melakukan proses membaca danmenulis". Literitas keuangan merupakan aspek 
paling penting dalam kehidupan dimana individu harus memiliki suatu pengetahuan dan keterampilan untuk mengelola sumber keuangan pribadinya secara efektif demi kesejahteraannya.

\section{b. Kontrol Diri}

Kontrol diri merupakan hal yang penting sebelum seseorang memutuskan untuk mengambil keputusan dalam berperilaku. Seseorang yang memilikikontrol diri yang tinggi maka akan cenderung mengendalikan penggunaanuangnya dan dapat melalukan pengelolaan uang dengan lebih baik sehingga akan menghindari perilakukonsumtif.

Kontrol diri adalah kemampuan individu untuk menahan dorongan- dorongan dan kemampuan individu untukmengendalikan tingkah lakunya pada saattidak adanya kontrol dari lingkungan. Menurut Fattah, Mintasih, \& Sunarto (2018) kontrol diri merupakan "suatu kecakapan individu dalam membaca situasi atau kondisi tertentu, mengandung makna yaitu dalam melakukan sesuatu seseorang mempertimbangkan terlebih dahulu mana yang baik dan mana yang benar sebelum melakukan tindakan.Semakin tinggi kontrol diri seseorang maka semakin tinggi pula kontrol tingkahlaku orang tersebut. Kontrol diri membantu mancapai keberhasilan dalam jangka panjang atau tujuan yang lebih tinggi dengan mengesampingkan kesenangan jangka pendek."

\section{c. $\quad$ Electronic Money}

Uang elektronik (e-money) adalahalat pembayaran elektronik yang diperoleh dengan menyetorkan terlebih dahulu sejumlah uang kepada penerbit,baik secara langsung, maupun melalui agen-agen penerbit, atau denganpendebitan rekening di bank, dan nilai uang tersebut dimasukan menjadi nilai uang dalam media uang elektronik, yang dinyatakan dalam satuan rupiah, yangdigunakan untuk melakukan transaksipembayaran dengan cara mengurangi secara langsung nilai uang pada mediauang elektronik tersebut. Menurut Ramadani (2016) uang elektronik merupakan "produk yang memiliki nilai tersimpan (stored value) atau prabayar (prepaid) dimana sejumlah uang disimpan dalam suatu media elektronis yang dimiliki seseorang. Uang elektronik (e-money) merupakan alat pembayaran yang dapat digunakan untuk berbagai macam jenis pembayaran (multi purposed), tidak seperti kartu telepon yang merupakan single purpose prepaid card".

\section{d. Perilaku konsumtif}

Perilaku merupakan suatu kegiatan atau aktivitas individu bersangkutan. Perilaku manusia pada hakikatnya adalah suatu aktivitas dari pada manusia itu sendiri. Perilaku adalah apa yang dikerjakan oleh individu baik yang bisa diamati secara langsung maupun tidak langsung. Perilaku baru akan terjadi apabila ada sesuatu yang diperlukan untuk menimbulkan reaksi, yakni rangsangan. Dengan demikian perilaku konsumtif merupakan perilaku seseorang dalam membeli barang berdasarkan keinginan bukan berdasarkan kebutuhan.

Menurut Chita, Lydia, \& Cicilia (2015) perilaku konsumtif adalah "kecenderungan perilaku manusia untukmelakukan konsumsi tiada batas, membeli sesuatu yang berlebihan atau secara tidak terencana".

Sedangkan menurut Dikria \& Sri (2016) perilaku konsumtif adalah "kecenderungan 
membeli atau mengkonsumsi barang-barang yang sebenarnya kurang diperlukan secara berlebihan serta tidak didasarkan atas pertimbangan yang rasional dimana karena individu lebih mementingkan faktor keinginan dari pada kebutuhan". Menurut Dikria \& Sri (2016) perilaku konsumtif juga diartikan sebagai "suatutindakan memakai produk yang tidaktuntas, artinya belum habis sebuah produkyang dipakai seseorang telahmenggunakan produk jenis yang sama dari merek lainnya atau dapat disebutkan, membeli barang karena adanya hadiah yang ditawarkan atau membeli suatu produk karena banyak orang memakai barang tersebut”.

\section{Metode Penelitian}

Dalam penelitian ini, peneliti menggunakan data primer dan data sekunder. Data primer, yaitu data yangdiperoleh langsung dari respondenmelalui prasurvei dan kuesioner kepada responden. Data sekunder, yaitu datayang diperoleh melalui dokumen dari pihak perusahaan yang diteliti, serta melalui situs dokumen lainnya seperti buku, jurnal, dan situs internet untuk mendukung penelitian. Populasi dalam penelitian ini adalah para pekerja produksi PT Pertamina Balikpapansejumlah 200 pekerja. Untuk menentukanjumlah sampel dalam penelitian ini penulis menggunakan rumus Slovin,

berikut adalah perhitungannya: pengetahuan (knowledge), keterampilan(skill), dan keyakinan (confidence)

$$
\begin{gathered}
\mathrm{n}=\frac{\mathrm{N}}{1+\left({\mathrm{N} \cdot \mathrm{e}^{2}}^{2}\right)} \\
\text { dimana: } \mathrm{n}=\frac{200}{1+\left(200 \times 0,05^{2}\right)} \\
=133
\end{gathered}
$$

seseorang agar mampu mengelola keuangan pribadi dengan lebih baik. Dari beberapa contoh indikator yang digunakan

$$
\begin{array}{ll}
n: & \text { Jumlah Sampel } \\
\text { N: } & \text { Jumlah Populasi } \\
\text { e: } & \text { Error Tolerance }
\end{array}
$$

Dari perhitungan tersebut diketahui sampel yang diambil adalah 133 pekerja yang dipilih menggunakan teknik simple random sampling. Untuk penentuan skor,menggunakan teknik pengukuran skala Likert. dengan angka (skor) tertinggiadalah 5 jawaban yang paling mendekati ideal dan angka (skor) 1 untuk jawaban yang paling jauh dari ideal.

Tabel Daftar Kriteria Penilaian JawabanKuesioner
\begin{tabular}{|c|c|c|}
\hline No & Kriteria/kategorijawaban & Nilai/skorJawaban \\
\hline 1 & Sangat setuju & 5 \\
\hline 2 & Setuju & 4 \\
\hline 3 & Ragu-ragu & 3 \\
\hline 4 & Tidak setuju & 2 \\
\hline
\end{tabular}




\begin{tabular}{|l|l|l|}
\hline 5 & Sangat tidak setuju & 1 \\
\hline
\end{tabular}

Penelitian ini dilakukan di PT Pertamina Balikpapan dengan objek penelitian para pekerja produksi. Waktu penelitian dimulai dari bulan agustus sampai September 2020. Teknik pengumpulan data dengan cara pembagian angket (questionare) yaitumemberi seperangkat pertanyaan dan pernyataan tertulis kepada responden untuk dijawab oleh para pekerja produksi PT Pertamina Balikpapan yang terpilih sebagai responden

\section{Definisi operasional variabel}

1. Literasi Keuangan $\left(\mathrm{X}_{1}\right)$

Suatu rangkaian proses atau kegiatan untuk meningkatkan sebelumnya berikut ini indikator literasikeuangan yang digunakan dalampenelitian ini:

1. Pengetahuan umum keuangan.

2. Pengetahuan manajemen keuangan.

3. Pengetahuan terhadap nilai barang.

4. Perencanaan pensiun.

5. Pengetahuan mengenai resiko.

\section{2. $\quad$ Kontrol Diri $\left(\mathrm{X}_{2}\right)$}

Kontrol diri merupakan sebuah aktivitas yang dapat berfungsi untuk mendorong penghematan serta menekan pembelian impulsif (tujuan untuk kesenangan semata). Setelah mencermati aspek atau indikator kemudian menyesuaikan dengan kebutuhan penelitian maka berikut ini adalah indikator-indikator kontrol diri yang digunakan dalam penelitian ini:

1. Merencanakan sebelum membeli.

2. Membandingkan harga sebelum membeli.

3. Mempertimbangkan kegunaan barang.

4. Berpikir sebelum membeli barang yang sama.

5. Membeli barang yang sedang dibutuhkan.

\section{E-Money $\left(\mathrm{X}_{3}\right)$}

E-Money adalah suatu produk stored-value atau prepaid yang digunakan dalam transaksi internet dengan cara elektronik. Setelahmencermati aspek atau beberapa indikator kemudian menyesuaikan dengan kebutuhan penelitian maka berikut ini adalah indikator-indikator penggunaan e-money yang digunakan dalam penelitian ini:

1. Manfaat apa yang diperoleh.

2. Kemudahan yang diberikan.

3. Rasa kepercayaan ketika menggunakan.

4. Keuntungan apa yang diperoleh.

\section{Perilaku Konsumtif $(\mathrm{Y})$}


Perilaku konsumtif merupakansuatu perbuatan mengkonsumsi barang atau jasa diluar batas kebutuhan tanpa mempertimbangkan rasional dan hanya mementingkan keinginan semata yakni pembelian impulsif, pembelian tidak rasional, pemborosan dan inefesiensi biaya. Terdapat beberapa indikator- indikator yang digunakan untuk mengetahui tingkat perilaku konsumtif seseorang. Berikut ini adalah indikator-indikator perilaku konsumtif yangdigunakan dalam penelitian ini:

1. Membeli produk karena trend.

2. Membeli produk karena kemasan yang menarik.

3. Membeli produk atas diskon atau iming-imingan hadiah.

4. Membeli produk untukmenunjukan status sosial.

5. Membeli produk karena idolanya menjadi bintang iklan produk tersebut.

\section{Metode Analisis Data}

Dalam penelitian kuantitatif, teknik analisis data yang digunakan sudah jelas, yaitu diarahkan untuk menjawab rumusanmasalah atau menguji hipotesis yang telahdirumuskan dalam proposal. Karenadatanya kuantitatif, maka teknik analisis

data menggunakan metode statistik yang sudah tersedia.

\section{Analisis Statistik Deskriptif}

Metode pengumpulan data dalam penelitian ini dilakukan dengan analisis statistik deskriptif, yaitu dengan 133 kuesioner yang diisi oleh pekerja produksi PT Pertamina Balikpapan. Statistik deskriptif memberikan gambaran mengenai suatu data. Dalam hal ini, statistik deskriptif menjelaskan mengenai karakteristik responden dan variabel yangdigunakan.

\section{Analisis Linier Berganda}

Analisis data yang digunakan pada penelitian ini adalah analisis regresi linearberganda, yaitu analisis untuk mengetahuipengaruh literasi keuangan, kontrol diri, penggunaan e-money terhadap perilaku konsumtif. Bentuk persamaan dari analisaini adalah:

$$
\begin{aligned}
& \mathrm{Y}=\beta 0+\beta 1 \mathrm{X} 1+\beta 2 \mathrm{X} 2+\beta 3 \mathrm{X} 3+\varepsilon \\
& \text { Keterangan: } \\
& \mathrm{Y} \quad=\text { Perilaku Konsumtif } \beta 0=\text { Konstanta } \\
& \beta 1 \quad=\text { Koefisien Regresi X1X1 = Literasi Keuangan } \\
& \beta 2 \quad=\text { Koefisien Regresi X2X2 = Kontrol Diri } \\
& \beta 3 \quad=\text { Koefisien Regresi X3X3 = E-Money } \\
& \varepsilon \quad=\text { Tingkat Kesalahan (error ofterm) }
\end{aligned}
$$

\section{Uji Multikolinearitas}

Menurut Ghozali (2018:22) uji multikolonieritas bertujuan “untuk menguji apakah model regresi ditemukan adanya korelasi antar variabel bebas (independen)". Model regresi yang baik seharusnya tidak terjadi korelasi di antaravariabel bebasnya.

\section{Uji Autokorelasi}


Menurut Ghozali (2018:122) uji autokorelasi bertujuan "menguji apakahdalam regresi linear ada korelasi antara kesalahan pengganggu pada periode $t$ dengan kesalahan pengganggu pada periode t-1 (sebelumnya)". Autokorelasi muncul karena observasi yang berurutan sepanjang waktu berkaitan satu sama lain. Masalah ini timbul karena residual (kesalahan pengganggu) tidak bebas dari satu observasi ke observasi lainnya.

\section{Uji Heteroskedastisitas}

Menurut Ghozali (2018) uji heteroskedastisitas bertujuan "untuk menguji apakah dalam model regresiterjadi ketidaksamaan variance dari residual satu pengamatan ke pengamatan yang lain". Jika variance dari satu residual pengamatan ke pengamatan lain tetap, maka disebut sebagai Homoskedastisitas dan jika berbeda disebut Heteroskedastisitas.

\section{Uji Normalitas}

Menurut Ghozali (2018:122) uji normalitas bertujuan "untuk menguji apakah model regresi, variabelpengganggu atau residual memiliki distribusi normal". Untuk menguji apakah residual penelitian terdistribusi normal maka digunakan pengujian Kolmogorov-Smirnov Goodness of Fit Test terhadap masing-masing variabel. Suatu data dikategorikan sebagai distribusi normal jika data tersebut tingkat signifikan $(\alpha)>0.05$, maka terdistribusi normal.

\section{Uji Signifikansi Pengaruh Simultan(Uji F)}

Menurut Ghozali (2018:122) "pengujianini dilakukan untuk mengetahui signifikansi dari seluruh variabel bebas secara bersama-sama atau secara simultanterhadap variabel terikat". Bentuk pengujiannya adalah:

$\mathrm{H} 0: \beta 1=\beta 2=\beta 3=0$, artinya secarasimultan tidak terdapat pengaruh yang signifikan dari variabel bebas terhadap variabel terikat.

Ha: Minimal satu $\beta i \neq 0$, artinya secara simultan terdapat pengaruh yangsignifikan dari variabel bebas terhadap variabel terikat.

Kriteria pengambilan keputusan:

1. H0 diterima (Ha ditolak), jika $F$ hitung $\leq \mathrm{F}$ tabel pada $\alpha=5 \%$ atau sig. $\mathrm{F} \geq \alpha(0,05)$

2. Ha diterima (H0 ditolak), jika $F$ hitung $>F$ tabel pada $\alpha=5 \%$ atau sig. $F<\alpha(0,05)$

\section{Uji Signifikansi Pengaruh Parsial (Ujit)}

Menurut Ghozali (2018:122) uji t dilakukan "untuk mengetahui signifikansidari masingmasing variabel independen terhadap variabel dependen". Dengan kriteria pengambila keputusan two tailed.

Kriteria pengambilan keputusan:

1. H0 diterima (Ha ditolak), jika nilai sig $>0,05$ dan $-\mathrm{t}$ tabel $\leq \mathrm{t}$ hitung $\leq \mathrm{t}$ tabel pada $\alpha=$ $5 \%$

2. Ha diterima (H0 ditolak), jika nilai sig $<0,05$ dan $-\mathrm{t}$ hitung $<-\mathrm{t}$ tabel atau $\mathrm{t}$ hitung $>\mathrm{t}$ tabel pada $\alpha=5 \%$ 


\section{Koefisien Determinasi $\left(\mathbf{R}^{2}\right)$}

Menurut Ghozali (2018:122) koefisiendeterminasi $\left(\mathrm{R}^{2}\right)$ "digunakan untuk mengukur seberapa jauh kemampuan model dalam menerangkan variasi variabel dependen". Nilai Adjusted Squared $\left(\mathrm{R}^{2}\right)$ adalah koefisien

determinasi yaitu koefisien yangmenjelaskan seberapa besar proporsi variasi dalam dependen yang dapat dijelaskan oleh variabel-variabel independen secara bersama-sama. Nilai $\mathrm{R}^{2}$ koefisien determinasi berkisar antara $0-1$. Nilai $R^{2}$ sama dengan nol $\left(R^{2}=0\right)$ menunjukkan bahwa tidak ada pengaruh antara variabel bebas terhadap variabel terikat. Bila $\mathrm{R}^{2}$ semakin besar mendekati

1 menunjukkan semakin kuat pengaruhvariabel bebas tehadap variabel dan bila $\mathrm{R}^{2}$ semakin kecil mendekati 0 menunjukkan semakin kecil pengaruhvariabel bebas terhadap variabel terikat.

\section{Uji Validitas}

Uji Validitas ini dilakukan untuk mengetahui sejauh mana alat ukur yang akan dipakai apakah sudah benar-benarbias digunakan untuk mengukur apa yangakan diukur. Pada Uji validitas ini menggunakan sejumlah 133 responden yang terdiri dari variable bebas yaitu literasi keuangan, kontrol diri dan penggunaan e-money serta variable terikatnya yaitu perilaku konsumtif. Dalam penelitian ini perbandingan dari dalam untuk menguji alat ukur yang berupa kuesioner yaitu korelasi antara tiap butir kuesioner dengan total butir kuesioner. Angka korelasi (r) hitung yangdiperoleh kemudian dibandingkan denganangket (r) yang terdapat pada tabel dengan tingkat kesalahan 5\% dan jumlah $\mathrm{n}=133$, maka diperoleh $\mathrm{r}$ tabel 0,170. Jika $r_{\text {hitung }}<r_{\text {tabel }}$ maka butir instrument tersebut tidak valid.

Tabel Hasil Uji Validitas
\begin{tabular}{|c|c|c|c|}
\hline Item & R hitung & R tabel & Ket \\
\hline X1.1 & 0,642 & 0,170 & Valid \\
\hline X1.2 & 0,706 & 0,170 & Valid \\
\hline X1.3 & 0,692 & 0,170 & Valid \\
\hline X1.4 & 0,803 & 0,170 & Valid \\
\hline X1.5 & 0,774 & 0,170 & Valid \\
\hline X2.1 & 0,736 & 0,170 & Valid \\
\hline X2.2 & 0,765 & 0,170 & Valid \\
\hline X2.3 & 0,763 & 0,170 & Valid \\
\hline X2.4 & 0,792 & 0,170 & Valid \\
\hline X2.5 & 0,775 & 0,170 & Valid \\
\hline X3.1 & 0,793 & 0,170 & Valid \\
\hline X3.2 & 0,734 & 0,170 & Valid \\
\hline X3.3 & 0,654 & 0,170 & Valid \\
\hline X3.4 & 0,761 & 0,170 & Valid \\
\hline Y1 & 0,750 & 0,170 & Valid \\
\hline Y2 & 0,708 & 0,170 & Valid \\
\hline
\end{tabular}




\begin{tabular}{|c|c|c|c|}
\hline Y3 & 0,676 & 0,170 & Valid \\
\hline Y4 & 0,628 & 0,170 & Valid \\
\hline Y5 & 0,728 & 0,170 & Valid \\
\hline
\end{tabular}

Sumber: Data Diolah SPSS

Berdasarkan tabel diatas hasil uji validitas, diketahui bahwa seluruh itempertanyaan yang digunakan dalampenelitian ini adalah valid, nilai darimasing-masing item pertanyaan memiliki nilai Pearson Corelation positif dan lebihbesar dari pada nilai $r_{\text {tabel }}$ yaitu 0,170.

\section{Uji Reliabilitas}

Uji reliabilitas (uji keandalan) adalah sejauh mana alat pengukur dapat dipercaya atau dapat diandalkan bila suatu alat pengukur digunakan dua kaliuntuk mengukur gejala yang sama dan hasil pengukuran yang diperoleh relative konsisten. Uji reliabilitas ini dilakukan dengan cara menggunakan rumus Cronbach' Alpha, kemudian dari hasil korelasi dibandingkan dengan nilai krisis pada taraf signifikan 0,70. Jika koefisien korelasi lebih kecil dari nilai krisis, maka pengukuran tersebut tidak reliabel atau tidak dapat diandalkan, berikut hasil uji reliabilitas pada tiap angket memperoleh hasil sebagai berikut:

Tabel Uji Reliabilitas

\begin{tabular}{|l|l|l|}
\hline Variabel & $\begin{array}{c}\text { Cronbanch's } \\
\text { Alpha }\end{array}$ & Status \\
\hline $\mathrm{X} 1$ & 0,775 & Reliabel \\
\hline $\mathrm{X} 2$ & 0,821 & Reliabel \\
\hline $\mathrm{X} 3$ & 0,718 & Reliabel \\
\hline $\mathrm{Y}$ & 0,737 & Reliabel \\
\hline
\end{tabular}

Sumber: Data Diolah SPS

Hasil uji reliabilitas terhadap angketliterasi kueangan $(\mathrm{X} 1)=0,775$, kontroldiri $(\mathrm{X} 2)=$ 0,821 , e-money $(\mathrm{X} 3)=0,718$ dan perilaku konsumtif $(\mathrm{Y})=0,737$ diperoleh koefisien reliabilitas masing- masing nilai Cronbanch'S Alpha tersebutlebih besar dari nilai kritis pada taraf signifikansi 5\% yaitu sebesar 0.70sehingga seluruh angket dinyatakan reliabel, dan dapat disimpulkan bahwa data yang dikumpulkan melalui angket dinyatakan reliabilitas dan dapat dipercaya.

Analisis Regresi Linier Berganda

\begin{tabular}{|l|l|c|}
\hline \multicolumn{2}{|c|}{ Model } & Unstandardized Coefficients \\
\cline { 2 - 3 } & (Constant) & B \\
\cline { 2 - 3 } & LITERASI KEUANGAN(X1) & 14.883 \\
\cline { 2 - 3 } & KONTROL DIRI(X2) & -.354 \\
\hline
\end{tabular}




\begin{tabular}{|l|c|}
\hline$E-M O N E Y(\mathrm{X} 3)$ & .303 \\
\hline
\end{tabular}

Sumber: Data Diolah SPSS

Dengan penjelasan sebagai berikut:

1. Nilai konstanta sebesar 14,883 inimempunyai arti bahwa semua variabel independen (literasikeuangan, kontrol diri dan electronic money) yang ditelitidianggap konstan maka tingkat variabel perilaku konsumtif (Y) tetap sebesar 14,883.

2. Nilai koefisien regresi dari variabel literasi keuangan adalah 0,354 bernilai negatif. Artinya literasi keuangan berpengaruh negatif terhadap perilaku konsumtif. Jika variabel literasi keuangan (X1) ditingkatkan maka variabel perilakukonsumtif (Y) akan menurun.

3. Nilai koefisien regresi dari variabel kontrol diri adalah 0,173 berilai negatif. Artinya kontrol diri berpengaruh negatif terhadap perilaku konsumtif. Jika variabel kontrol diri (X2) ditingkatkan makavariabel perilaku konsumtif (Y) akan menurun.

4. Nilai koefisien regresi dari variabel e-money adalah 0,303 bernilai positif. Artinya e-moneyberpengaruh positif terhadapperilaku konsumtif. Jika variabel $e$ - money (X3) ditingkatkan maka variabel perilaku konsumtif (Y) akan meningkat.

Uji Multikolinearitas

\begin{tabular}{|l|c|c|}
\hline \multirow{2}{*}{\multicolumn{1}{|c|}{ Model }} & \multicolumn{2}{c|}{ CollinearityStatistics } \\
\cline { 2 - 3 } & Tolerance & VIF \\
\hline LITERASI KEUANGAN(X1) & .762 & 1.312 \\
\hline KONTROL DIRI(X2) & .851 & 1.175 \\
\hline E-MONEY $(\mathrm{X} 3)$ & .796 & 1.256 \\
\hline
\end{tabular}

Berdasarkan tabel ujimultikolinearitas diatas diketahui:

1. Nilai VIF dari variabel literasi keuangan adalah $1,312<10$ dan nilai Tolerance 0,762 $>0,1$ maka diindikasi tidak terjadimultikolinearitas.

2. Nilai VIF dari kontrol diri adalah $1,175<10$ dan nilai Tolerance $0,851>0,1$ maka diindikasi tidak terjadi multikolinearitas.

3. Nilai VIF dari e-money adalah $1,256<10$ nilai dan Tolerance $0,796>0,1$ maka diindikasi tidak terjadi multikolinearitas.

Karena seluruh nilai VIF $<10$ dan nilai Tolerance $>0,1$, maka diindikasi tidak terjadi multikolinearitas.

\section{Uji Autokorelasi}

Dari hasil DW hitung sebesar 1,788dan nilai du dari tabel sebesar 1,7631 dan sedangkan nilai dl dari tabel sebesar 1,6710 maka kesimpulannya du $<\mathrm{dw}<4$ - du atau 1,7631 <1,788< 2,2369 dengandemikian tidak terjadi autokorelasi. 


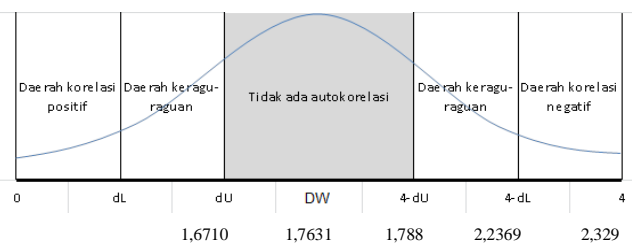

\section{Uji Heteroskedastisitas}

Uji heterokedastisitas dengan menggunakan grafik scatterplot dinyatakan tidak terjadi heterokedastisitasapabila titik-titik data menyebar di atasdan di bawah angka 0 .

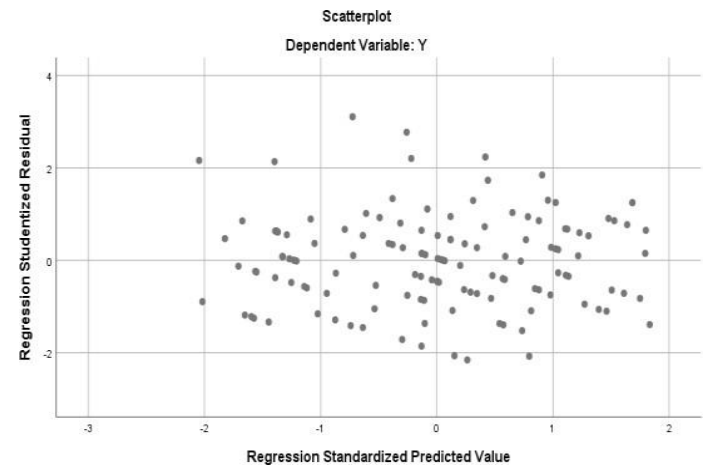

Maka dapat disimpulkan bahwa model regresi yang digunakan ada Kemungkinan terjadi gejalaheteroskedastisitas. Untuk lebihdetailnya, uji heteroskedastisitas akan diuji glejser agar memperoleh data yang berbentuk angka.

\begin{tabular}{|c|c|c|c|}
\hline & $\begin{array}{c}\text { Mode } \\
1\end{array}$ & \multicolumn{2}{|c|}{ Sig. } \\
\hline & (Constant) & \multicolumn{2}{|c|}{.128} \\
\hline 1 & $\begin{array}{l}\text { LITERASI } \\
\text { KEUANGAN }(\mathrm{X} 1)\end{array}$ & \multicolumn{2}{|c|}{.614} \\
\hline & $\begin{array}{l}\text { KONTROL DIRI } \\
(\mathrm{X} 2)\end{array}$ & \multicolumn{2}{|c|}{.292} \\
\hline & $E-M O N E Y(\mathrm{X} 3)$ & \multicolumn{2}{|c|}{.982} \\
\hline \multirow{3}{*}{1} & Regression & $\begin{array}{l}26.13 \\
9\end{array}$ & $.000^{\mathrm{b}}$ \\
\hline & Residual & & \\
\hline & Total & & \\
\hline
\end{tabular}

Sumber: Data Diolah SPSS

Terlihat nilai signifikansi variabelliterasi keuangan (X1) 0,614>0,05, kontrol diri (X2) 0,292 > 0,05 dan $e$ - money (X3) 0,982>0,05. Sehingga dapatditarik kesimpulan bahwa model regresi tidak mengandung adanyaheteroskedastisitas. 


\section{Uji Normalitas}

Ada dua cara untuk mendeteksi apakah data berdistribusi normal atau tidak, yaitu dengan pendekatan grafik danpendekatan statistik.

1. Pendekatan Grafik

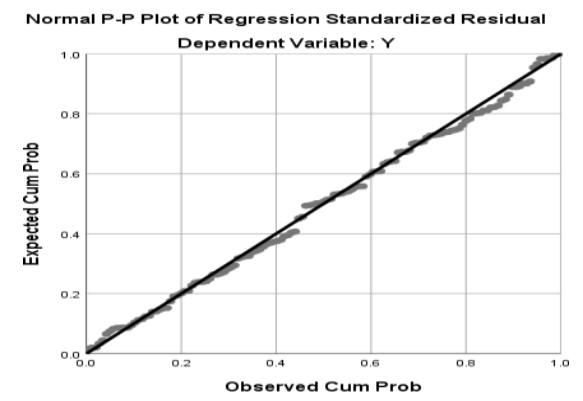

Pada p-plot terlihat bahwa titik-titikmenyebar disekitar garis diagonal dan cenderung mengikuti arah garis diagonal.

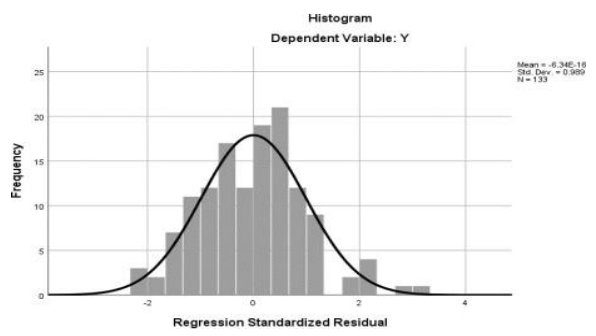

Berdasarkan grafik dapat disimpulkan bahwa distribusi data normal karena grafik histogram menunjukkanpola distribusi normal.

\section{Pendekatan Statistik}

Berdasarkan data perhitunganSPSS, nilai Asymp.Sig. (2-tailed) adalah 0,200, ini berarti nilainya diatas nilai signifikan 5\% (0,05). Oleh karena itu, sesuai dengan analisis grafik, analisis statistik dengan uji statistik nonparametrik Kolmogorov-Smirnov (K-S) juga menyatakan bahwa variabel residual berdistribusi normal.

\section{Uji Signifikansi Pengaruh Simultan(Uji F)}

Uji ini dilakukan denganmembandingkan signifikansi nilai f hitung $>\mathrm{f}$ tabel dan nilai probabilitas kurang dari 0,05. Jika model regresisudah sesuai dengan model tersebut makadapat dikatakan memiliki pengaruh secarabersama. Pada penelitian ini diketahui jumlah sampel (n) adalah 133 dan jumlah variabel bebas (k) adalah 3. Dengan itu terlebih dahulu mencari nilai koordinat pada tabel $\mathrm{f}$ seperti berikut:

$\mathrm{F}$ tabel $=(\mathrm{k} ; \mathrm{n}-\mathrm{k})$

$\mathrm{F}$ tabel $=(3 ; 130)=2,67$

Model|F| Sig.

Diperoleh nilai f tabel $=2,67$ dengan tingkat kesalahan 5\%.

Sumber: Data Diolah SPSS 
Dapat dilihat bahwa $\mathrm{f}$ hitung adalah 26,139 dengan tingkat signifikansi 0,000. Sedangkan $\mathrm{f}$ tabel pada tingkat kepercayaan $95 \%(\alpha=0,05)$ adalah 2,67 . Oleh karena itu, $\mathrm{f}$ hitung $(26,139)>\mathrm{f}$ tabel $(2,67)$ dan tingkat signifikansinya $0,000<0,05$ menunjukkan bahwa variabel independen (literasi keuangan, kontrol diri, e-money) secara simultan adalah berpengaruh signifikan terhadap perilaku konsumtif para pekerja produksi PT Pertamina RU V Balikpapan.

\section{Uji Signifikansi Pengaruh Parsial (Ujit)}

Uji ini dilakukan denganmembandingkan signifikansi nilai $t$ hitung $>t$ tabel dan nilai probabilitas kurang dari 0,05. Pada penelitian ini diketahui jumlah sampel (n) adalah 133 dan jumlah variabel bebas (k) adalah 3 . Dengan itu terlebih dahulu mencari nilai koordinat pada tabel $\mathrm{t}$ serta terlampir grafik two tailed agar lebih mudah untuk memahami dalam pengambilan keputusanseperti berikut:

$$
\begin{aligned}
& \mathrm{t} \text { tabel }=(\alpha / 2 ; \mathrm{n}-\mathrm{k}-1) \\
& \mathrm{t} \text { tabel }=(0,05 / 2 ; 133-3-1)=1,9785
\end{aligned}
$$

\begin{tabular}{|c|c|c|c|}
\hline \multirow{2}{*}{ Model } & \multicolumn{2}{|c|}{$\mathrm{t}$} & \multirow{2}{*}{ sig } \\
\cline { 2 - 3 } & hitung & tabel & \\
\hline $\begin{array}{c}\text { LITERASI } \\
\text { KEUANGAN } \\
(\mathrm{X} 1)\end{array}$ & -4.454 & $-1,9785$ & 0.000 \\
\hline $\begin{array}{c}\text { KONTROL } \\
\text { DIRI (X2) }\end{array}$ & -2.268 & $-1,9785$ & 0.000 \\
\hline $\begin{array}{c}E-M O N E Y \\
(\mathrm{X} 3)\end{array}$ & 3.466 & 1,9785 & 0.001 \\
\hline
\end{tabular}

Sumber: Data Diolah SPSS

Berdasarkan tabel diatas dapatdisimpulkan sebagai berikut:

1. Literasi Keuangan (X1)

Variabel literasi keuanganberpengaruh negatif dan signifikan terhadap perilaku konsumtif pekerjaproduksi PT Pertamina RU V Balikpapan. Hal ini terlihat dari nilai signifikan 0,00 $<0,05$, dan -t hitung $(-4,454)<-t$ tabel $(-1,9785)$. Artinya jika variabel literasikeuangan ditingkatkan maka berpengaruhterhadap menurunnya variabel perilaku konsumtif.

\section{Kontrol Diri (X2)}

Variabel kontrol diri berpengaruh negatif dan signifikan terhadap perilaku konsumtif pekerja produksi PT PertaminaRU V Balikpapan. Hal ini terlihat darinilai signifikan 0,025 $<0,05$, dan -t hitung $(-2,268)<-t$ tabel $(-1,9785)$. Artinya jika variabel kontrol diri ditingkatkan maka berpengaruh terhadap menurunnya variabel perilaku konsumtif.

\section{E-Money $(\mathrm{X} 2)$}


Variabel electronic money berpengaruh positif dan signifikanterhadap perilaku konsumtif pekerjaproduksi PT Pertamina RU V Balikpapan. Hal ini terlihat dari nilai signifikan 0,001 $<0,05$, dan $t$ hitung $(3,466)>\mathrm{t}$ tabel $(1,9785)$. Artinya jika variabel electronic money ditingkatkan maka variabelperilaku konsumtif secara signifikan akanmeningkat.

\section{Koefisien Determinasi $\left(\mathbf{R}^{2}\right)$}

Koefisien determinasi yaitu koefisien yang menjelaskan seberapa besar proporsi variasi dalam dependen yang dapat dijelaskan oleh variabel-

variabel independen secara bersama- sama. Berdasarkan hasil uji SPSS terlihat bahwa nilai Adjusted R Square sebesar0,364 berarti 36,4\% variasi perilaku konsumtif dapat dijelaskan oleh literasikeuangan (X1), kontrol diri (X2), dan $e$ - money (X3). Sedangkan sisanya sebesar $63,6 \%$ dijelaskan oleh variasi lain yang tidak diteliti dalam penelitian ini.

\section{Kesimpulan}

1. Secara simultan literitasi keuangan, kontrol diri, dan penggunaan $e$ - money berpengaruh terhadap perilaku konsumtif pada pekerjaproduksi PT Pertamina RU V Balikpapan.

2. Secara parsial literasi keuangan berpengaruh negatif dan signifikan terhadap perilaku konsumtif pada pekerja produksi PT Pertamina RU V Balikpapan.

3. Secara parsial kontrol diri berpengaruh negatif dan signifikan terhadap perilaku konsumtif pada pekerja produksi PT Pertamina RU V Balikpapan.

4. Secara parsial penggunaan e-money berpengaruh positif dan signifikan terhadap perilaku konsumtif pada pekerja produksi PT Pertamina RU V Balikpapan.

\section{Saran}

1. Bagi para pekerja produksi RU V Balikpapan disarankan untuk tidak terjebak dalam perilaku konsumtif. Cara yang dapat dilakukan adalahmeningkatkan tingkat literasi keuangan, memperkuat kontrol diri sehingga dapat mengontrol dan mengendalikan pembelian impulsif, serta bijak dalam menggunakan electronic money.

2. Bagi perusahaan tepatnya PT Pertamina Balikpapandiharapkan dari penelitian ini dapat bermanfaat sebagai bahanpertimbangan dalam memahamikarakteristik pekerja terutama pada proses pendewasaan serta bahaya perilaku konsumtif. Sehingga dapat meningkatkan dalam segi intelektual, moral dan nilai.

3. Bagi pemerintah disarankan agar lebih sering mengadakan edukasi mengenai literasi keuangan sejak dini seperti lebih sering diadakan edukasi berupa seminar, workshop dan gerakan yang dapat memicu seseorang untuk memahami danmenerapkan pentingnya literasi keuangan.

4. Bagi peneliti selanjutnya disarankanuntuk menggunakan variabel lain yang dianggap dapat mempengaruhiperilaku konsumtif. Selain itu ruanglingkup dari penelitian diperluas lagi sehingga pengambilan sampel dapat lebih beragam dan bervariasi.

\section{DAFTAR PUSTAKA}




\section{JESYA}

JURNAL EKONOMI \& EKONOMI SYARIAH

Jurnal Ekonomi \& Ekonomi Syariah Vol 5 No 1, Januari 2022

E-ISSN : 2599-3410 | P-ISSN : 2614-3259

DOI : https://doi.org/10.36778/jesya.v5i1.574

Chita, R. C. M., Lydia D., \& Cicilia P. 2015. Hubungan Antara Self Control Dengan Perilaku Konsumtif Online ShoppingProduk Fashion Pada Mahasiswa Fakultas Kedokteran Universitas Sam Ratulangi Angkatan 2011. Jurnal E-Biomedik, 3 (1). 297-302.

Dikria, O., \& Sri U. M. W. 2016.Pengaruh Literasi Keuangan danPengendalianDiri Terhadap Perilaku Konsumtif Mahasiswa Jurusan Ekonomi PembangunanFakultas Ekonomi Universitas Negeri Malang Angkatan 2013. Jurnal Pendidikan Ekonomi,9 (2).128139

Fattah, F. A., Mintasih Indriayu, \& Sunarto. 2018. Pengaruh Literasi Keuangan dan Pengendalian Diri Terhadap Perilaku Konsumtif Siswa SMA Muhammadiyah 1 Karanganyar. Jurnal PendidikanBisnis dan Ekonomi, 4 (1). 11-21.

Ghozali, Imam. 2018. Aplikasi AnalisisMultivariate Dengan ProgramIBM SPSS 25 Edisi 9. Semarang : Badan Penerbit Undip.

Ramadani, Laila. 2016. Pengaruh Penggunaan Kartu Debit danUang Elektronik E-Money Terhadap Pengeluaran KonsumsiMahasiswa. JESP, 8 (1). 1-8.

Soetiono, K. S., \& Cecep Setiawan. 2018.Literasi dan Inklusi Keuangan Indonesia. Depok : Raja Grafindo Persada.] 